\title{
Pengaruh Pola Makan terhadap Kadar Hemoglobin pada Anak Pra Sekolah
}

\author{
Rosalinna $^{1^{*}, \text { Sugita }^{2}}$ \\ ${ }^{1,2}$ Poltekkes Kemenkes Surakarta Jurusan Kebidanan \\ *Email: rosalinasetianto@gmail.com
}

\begin{abstract}
Background: Pre school children need adequate nutrition for growth and development, as one of the most vulnerable groups is primarily anemia. Nutritional disorders of anemia can be caused by various factors, one of which is a diet (amount, frequency and variety) that does not meet the balance. Objective to analyze The Effect of Diet on Hemoglobin Levels In Pre-School children. Methods: Cross-sectional study was conducted on 28 chlidren. Sampling is done by Purposive Sampling technique. Data collect from food Record and misson Hb. Data analyze used Pearson product moment correlation test and Multiple Regression Analysis. Results: The results of this study obtained the average hemoglobin level of children is $10.18(0.99)$. The results of the test on energy intake $(\rho=0.820)$, iron intake $(\rho=0.300)$, vitamin $C$ intake $(\rho=0.300)$ which states no significant relationship with hemoglobin levels. Protein intake $(\rho=0,007)$, variation $(\rho=0,000)$, and frequency $(\rho=-0,035)$ have significant relationship with hemoglobin level. Multivariate analysis of dietary variations significantly influenced hemoglobin levels in pre-school children $(\rho=0.000, r=0.0636 ; R 2=0.405)$. Conclusions: That daily intake, iron intake and vitamin $C$ alone have no effect on hemoglobin, but it is necessary to increase protein intake, eating frequency setting especially variation in food menu. Required intervention strategies to increase intake, selection of foodstuffs, processing, presentation to children for iron absorption and control of anemia can be solved.
\end{abstract}

Keywords: anemia, diet, hemoglobin

\section{PENDAHULUAN}

Anemia masih merupakan masalah kesehatan masyarakat yang utama di khususnya di negara berkembang. Lebih dari 273 juta anak di bawah lima tahun, menderita anemia di seluruh dunia. (Legason IL, Atiku A, Ssenyonga R, Olupot PO, \& Barugahare JB, 2017). Bayi dalam 6-24 bulan berisiko sangat tinggi, therapy anak-anak di seluruh periode prasekolah mungkin rentan, terutama di negara berkembang. (Malkanthi R. L. D. K. , Silva K. D. R. R. , \& Mudalige UKJ, 2010).

Prevalensi anemia usia pra sekolah di Indonesia pada tahun 2013 mencapai 28,1\% (Riskesdas, 2013). Di Kabupaten Karanganyar pada tahun 2013 dilakukan survey pada 340 balita yang mengalami anemia ada 107 balita. Penyebab anemia bervariasi menurut usia. Kebanyakan anak-anak dengan anemia tidak menunjukkan gejala dan kondisi terdeteksi pada pemeriksaan laboratorium (Janus J \& Moerschel SK, 2010). Kajian terbaru menunjukkan etiologi anemia bersifat multifaktorial dengan defisiensi mikronutrien merupakan faktor utama, beberapa penyebab diantaranya adalah infeksi, folat dan defisiensi besi (Chandyo RK, Ulak M, Adhikari RK, Sommerfelt H, \& Strand TA, 2015).

Kekurangan zat besi umumnya menyebabkan penurunan sel darah merah. Faktor risiko termasuk prematuritas, pola makan yang buruk, konsumsi lebih dari 24 ons sapi susu per hari, dan kehilangan darah kronis. Penyebab lain termasuk peradangan dari infeksi kronis atau kondisi peradangan lainnya, gagal ginjal, penggunaan obat-obatan, penyakit virus, dan gangguan sumsum tulang (Janus $\mathbf{J} \&$ Moerschel SK, 2010).

Menurut Saaka et al (2017) pola diet 
terdiri dari asupan makanan, variasi makanan dan frekuensi makan. Variasi didefinisikan keragaman makanan yang berbeda kelompok yang dikonsumsi selama periode referensi yang diberikan, memiliki telah diidentifikasi sebagai ukuran yang berguna untuk kualitas keseluruhan dan kecukupan gizi dari diet yang mungkin mempengaruhi pembentukan darah (Saaka M \& Galaa SZ, 2017).

Hasil penelitian Janus (2010) menyebutkan bahwa anak-anak yang kekurangan gizi secara kronis dapat berubungan dengan tingginya prevalensi anenmia. Pentingnya asupan gizi yang sesuai dengan Angka Kecukupan Gizi (AKG) dapat mengurangi kejadian anemia.

Pentingnya pemahaman tentang faktor risiko karena dampak dari anemia pada anak dapat terganggu pertumbuhan fisik, perubahan kekebalan tubuh dan peningkatan kerentanan terhadap infeksi, gangguan motorik, kemampuan cognitive, prestasi sekolah yang buruk dan mortalitas jangka pendek atau panjang pada kasus akut berat(Chandyo RK et al., 2015)

Penelitian ini bertujuan untuk mengetahui hubungan pola makan (jumlah, variasi dan frekuensi) dengan kejadian anemia pada anak usia pra sekolah.

\section{METODE PENELITIAN}

Penelitian ini menggunakan jenis pendekatan Observational Research dengan pendekatan cross sectional. Penelitian ini dilaksanakan pada bulan Maret 2017-Juni 2017. Tempat penelitian ini dilakukan di PAUD Kabupaten Karanganyar, Jawa Tengah.
Populasi yang diambil dalam penelitian ini adalah semua anak usia pra sekolah (3-6 tahun) di Kabupaten Karanganyar, Jawa Tengah. Pengambilan sampel dilakukan dengan teknik Purposive Sampling sehingga didapatkan sebanyak 428 sampel yang memenuhi kriteria inklusi dan eksklusi. Kriteria inklusi dalam penelitian ini yaitu: Anak usia pra sekolah usia 3-6 tahun yang ada pada saat pengambilan data, Anak usia pra sekolah usia 3-6 tahun yang terdaftar sebagai siswa PAUD di Kabupaten Karanganyar, Jawa Tengah saat dilakukan penelitian, Ibu dan anak bersedia menjadi responden, Anak dalam keadaan sehat. Kriteria eksklusi dalam penelitian ini yaitu ibu atau anak mengundurkan diri menjadi responden di tengah-tengah proses pengambilan data.

Pada penelitian ini instrumen yang akan digunakan berupa food record selama 7 hari berturut-turut menggunakan food list. Orang tua diminta untuk mencatat pola makan anak selama 1 minggu terakhir. Pedoman Gizi seimbang digunakan untuk mendapatkan jumlah makanan. Hasil kemudian di catat menggunakan program nutri survey. Pemeriksaan kadar hemoglobin dengan menggunakan alat Mission $\mathrm{Hb}$. Proses pengambilan data menggunakan enumerator bidan dan dietizen. Analisis statistik yang digunakan adalah uji korelasi product moment dan multiple regression analysis. Program komputer yang digunakan adalah SPSS for windows.

\section{HASIL PENELITIAN}

Penelitian ini analisis yang dilakukan untuk mengetahui distribusi dan presentase dari responden tentang pola makan dan kejadian anemia. Data dapat dilihat dalam bentuk tabel berikut: 

Tabel 1. Pola Makan pada Anak Usia Pra Sekolah

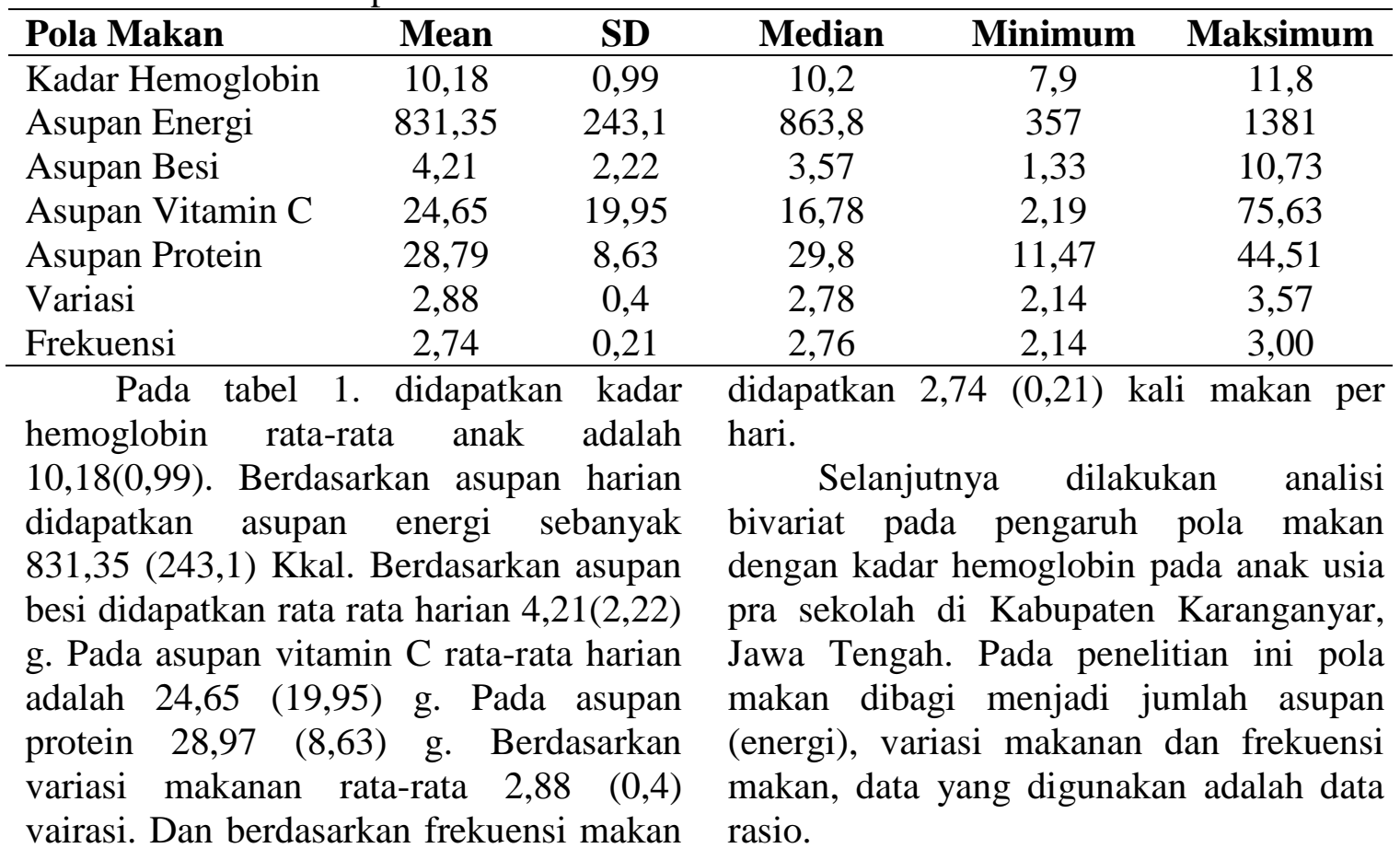

Tabel 2. Hubungan Pola Makan berdasarkan Jumlah (Asupan Energi), Variasi dan Frekuensi dengan Kadar Hemoglobin.

\begin{tabular}{lcc}
\hline Variabel & $\boldsymbol{\rho}$ value & $\boldsymbol{r}$ \\
\hline Asupan Energi & 0,820 & $-0,045$ \\
Asupan Besi & 0,300 & 0,203 \\
Asupan Vitamin C & 0,846 & $-0,038$ \\
Asupan Protein & 0,007 & 0,499 \\
Variasi & 0,000 & 0,636 \\
Frekuensi & 0,035 & 0,400 \\
\hline
\end{tabular}

Keterangan uji: *) korelasi pearson product moment

Hasil perhitungan penelitian tabel 2

Pada hubungan protein dengan didapatkan hubungan pola makan kadar hemoglobin didapatkan kekuatan berdasarkan jumlah, frekuensi dan variasi hubungan dengan nilai $r=0,499$ hal ini dengan kadar hemoglobin. Hasil uji pada menunjukkan bahwa kekuatan hubungan asupan energi $(\rho=0,820)$, asupan besi pada asupan protein dengan kadar $(\rho=0,300)$, asupan vitamin $C(\rho=0,300)$ hemoglobin adalah hubungan yang cukup yang menyatakan tidak ada Hubungan kuat. yang signifikan dengan kadar hemoglobin. Hasil penelitian ini jumlah rata-rata Berdasarkan asupan protein $(\rho=0,007)$, asupan protein $28,79 \mathrm{~g} / \mathrm{hari}$ kurang dari variasi $(\rho=0,000)$, dan frekuensi $(\rho=-$ AKG yaitu $35 \mathrm{~g} /$ hari. Protein berperan $0,035)$ yang menyatakan ada hubungan penting dalam pembentukan hemoglobin. yang signifikan dengan kadar hemoglobin. Oleh sebab itu terdapat hubungan protein 
dengan kadar hemoglobin.

Pada hubungan variasi makanan dengan kadar hemoglobin. berdasarkan kekuatan hubungan didapatkan bahwa nilai $r=0,636$ hal ini menunjukkan bahwa kekuatan hubungan pada variasi makanan dengan kadar hemoglobin adalah hubungan yang kuat.

Hubungan frekuensi makan dengan kadar hemoglobin didapatkan nilai $\mathrm{r}=0,445$ hal ini menunjukkan bahwa kekuatan hubungan pada frekuensi makan dengan kadar hemoglobin adalah hubungan yang cukup kuat.

Analisis selanjutnya yaitu pada pemodelan multivariat untuk melihat pengaruh pola makan (asupan energi, asupan besi, asupan vitamin $\mathrm{C}$, asupan protein, variasi dan frekuensi) terhadap kadar hemoglobin. Variabel yang berhubungan pada analisis sebelumnya adalah asupan protein, variasi dan frekuensi. Pada analisis bivariat asupan energi, besi dan vitamin $\mathrm{C}$ didapatkan nilai $\rho>0,25$. Namun peneliti menganggap bahwa faktor tersebut penting dalam penelitian sehingga peneliti tetap mengikutkan semua variable dalam pemodelan multivariat menggunakan mulitple regression analysis dengan alpha 0,05. Pemodelan mulitvariat ini menggunakan metode bacward dimana variabel yang dianggap tidak bermakna akan dieliminasi satu persatu dengan tidak merubah nilai $\mathrm{R}>10 \%$. Hasil pemodelan disajikan pada tabel 3 berikut:

Tabel 3. Pengaruh Pola Makan terhadap Kadar Hemoglobin pada Anak Pra Sekolah

\begin{tabular}{lcccccc}
\hline Model Awal & B & SE beta & Beta & $\mathbf{P}$ & $\mathbf{r}$ & $\mathbf{R}^{2}$ \\
\hline Keterangan & $-0,001$ & 0,001 & $-0,145$ & 0,467 & 0,673 & 0,454 \\
Asupan Energi & $-0,019$ & 0,101 & $-0,043$ & 0,851 & & \\
Asupan Besi & $-0,003$ & 0,010 & $-0,058$ & 0,773 & & \\
Asupan Vitamin C & 1,101 & 0,654 & 0,446 & 0,107 & & \\
Asupan Protein & 0,236 & 1,043 & 0,051 & 0,823 & & \\
Variasi & 0,034 & 0,029 & 0,299 & 0,246 & & \\
Frekuensi & 6,017 & 2,469 & & 0,024 & & \\
Konstanta & & & & & &
\end{tabular}

\section{Model Akhir}

\begin{tabular}{lcccccc}
\hline Keterangan & $\mathbf{B}$ & SE beta & Beta & $\mathbf{P}$ & $\mathbf{r}$ & $\mathbf{R}^{2}$ \\
\hline Variasi & 1,570 & 0,373 & 0,636 & 0,000 & 0,636 & 0,405 \\
Konstanta & 5,563 & 1,088 & & 0,000 & & \\
\hline
\end{tabular}

Pada tabel 3 merupakan hasil akhir. Pada pemodelan akhir dapatkan pemodelan multivariat pengaruh pola hanya variabel variasi makanan yang makan (asupan energi, asupan besi, berpengaruh signifikan dengan kadar asupan vitamin $\mathrm{C}$, asupan protein, variasi hemoglobin pada anak pra sekolah dan frekuensi) terhadap kadar hemoglobin $(\rho=0,000)$. Pada penelitian menunjukkan pada anak pra sekolah $(\mathrm{p}>0,05)$. Pada nilai $r=0,0636$ yang berarti variasi hasil pemodelan awal didapatkan seluruh makanan berhubungan kuat dengan kadar variabel tidak berpengaruh signifikan hemoglobin. Selanjutnya untuk melihat terhadap kadar hemoglobin. Kemudian pengaruh variasi makanan memberikan variabel dengan nilai $\rho$ yang paling besar dampak terhadap kadar hemoglobin dieliminasi sampai didapatkan pemodelan dengan melihat nilai koefisien determinan 
yaitu nilai $\mathrm{R}^{2}=0,405$. Berdasarkan hal tersebut menjelaskan bahwa variasi makanan berpengaruh $40,5 \%$ terhadap kadar hemoglobin pada anak pra sekolah. Analisis lebih lanjut didapatkan pemodelan multivariat sebagai berikut. Kadar hemoglobin $=1,570$ variasi + 5,563 .

\section{PEMBAHASAN}

Secara keseluruhan Anemia adalah masalah kesehatan global yang sangat besar pentingnya kesehatan masyarakat (Sun J, Zhang L, Cui J, Li S, \& Lu H, 2018). Anak-anak sangat rentan untuk anemia defisiensi zat besi karena peningkatan kebutuhan zat besi mereka dalam periode pertumbuhan yang cepat, terutama dalam 5 tahun pertama kehidupan (Sachdev HPS \& Gera T, 2013).

Dampak anemia dikaitkan dengan penurunan perkembangan motorik dan kinerja kognitif, seperti juga kelelahan, gangguan tidur, lekas marah, dan memori yang buruk dan kinerja sekolah (Chandyo RK et al., 2015).

Kami menggunakan rapid test mission $\mathrm{Hb}$ pada penelitian ini untuk memperkirakan $\mathrm{Hb}$. Meskipun penggunaan rapid test belum menjadi standar pada penelitian dalam perkiraan hemoglobin, namun alat kami telah diuji kalibrasi dan sudah disesuaikan dengan kepentingan penelitian dan divalidasi baik untuk tujuan ini.

Pada penelitian ini didapatkan kadar hemoglobin rata-rata anak adalah $10,18 \pm 0,99$. Hal ini menunjukkan bahwa selama ini anak menderita anemia. Hal ini sesuai dengan diagnosis WHO yang ditetapkan bahwa batasan kadar Hemoglobin adalah 11,0 gr/dl. Pada temuan ini rata-rata anak pra sekolah menderita anemia ringan. Nilai rata-rata yang didapatkan penelitian ini masih kurang dari standar WHO (WHO, 2011).

Sejalan dengan penelitian Malkathi et al (2010) yang menjelaskan bahwa anemia pada anak dapat disebabkan karena asupan gizi yang kurang secara terus menerus. Penelitian ini dilakukan di Sri Lanka pada anak-anak petani yang menyatakan bahwa asupan gizi yang rendah dan tidak sesuai dengan AKG dapat berpengaruh pada tingginya prevalensi anemia.

Penelitian ini dilakukan selama 7 hari observasi (foodrecord) terhadap pola makan, jumlah asupan harian, variasi makanan dan frekuensi makan. Peneliti dan enumerator melakukan pengawasan langsung pada penelitian ini berdasarkan jumlah, jenis dan variasi. Pada penelitian ini tidak didapatkan bias pada saat pengambilan data tentang pola makam.

Berbeda pada penelitian sebelumnya yang menjelaskan bawa besi berhubungan dengan kadar hemoglobin anak pra sekolah. Pada enelitian ini asupan energi besi dan vitamin $\mathrm{C}$ tidak berhubungan. Besi adalah mineral penting yang melakukan banyak biologis berfungsi dalam tubuh kita. Persyaratan besi sangat tinggi di usia yang lebih muda karena pertumbuhan yang cepat dengan tajam lipatan dalam massa tubuh tanpa lemak, assa sel darah merah dan volume darah yang meningkatkan kebutuhan zat besi untuk hemoglobin di darah dan mioglobin di otot (Sun J et al., 2018).

Namun demikian pembentukan hemoglobin tidak dapat terjadi tampa adanya mikronutrient lain, selain itu penyerapan besi dapat terganggu bila kombinasi makanan tidak tepat saat orang tua menyiapkan makanan untuk anaknya. Penelitian ini tidak sejalan dengan penelitian Gondim yang menjelaskan besi merupakan penyebab anemia dan 
defisiensi gizi yang besar besarnya yang terus mewakili kesehatan masyarakat (Gondim SSR et al., 2012).

Hal ini sejalan dengan kajian Chnadyo bahwa pada anak-anak di bawah 12 bulan, hanya sekitar $13 \%$ yang dilaporkan telah dikonsumsi makanan kaya zat besi (daging, ikan, unggas, atau telur) dalam 24 jam sebelumnya. Bijibijian, khususnya beras, yang menyediakan sebagian besar dari total kalori dalam diet, mengandung besi bioavaibilitas rendah dan fitat tinggi, yang mengganggu penyerapan zat besi. Penyerapan zat besi yang tersedia secara biologis tidak hanya tergantung pada konten sebenarnya tetapi juga pada vitamin $\mathrm{C}$, jumlah yang terikat pada besi heme, dan juga pada status asupan protein dan variasi sendiri sendiri dapat berpengaruh (Chandyo RK et al., 2015).

Sesuai dengan temuan pada penelitian ini yang menyatakan asupan protein, variasi dan frekuensi ada hubungan yang signifikan dengan kadar hemoglobin. Pada penelitian lain menjelaskan hubungan yang signifikan adalah diperoleh antara anemia defisiensi besi dan pendapatan bulanan keluarga; rendah konsumsi makanan sumber protein, asupan produk susu dan infeksi parasite (Desalegn A, Mossie A, \& Gedefaw L, 2014).

Anak-anak yang tidak mengkonsumsi makanan sumber protein 2,3 kali lebih mungkin menjadi anemia daripada mereka yang mengkonsumsi makanan sumber protein. Apalagi mereka yang tidak mengkonsumsi kalori cukup dan produk makanan dari susu lebih mungkin menjadi anemia. Ini menunjukkan asupan nutrisi yang buruk, terutama kurang konsumsi protein, faktor utama anemia defisiensi besi pada anakanak (Desalegn A et al., 2014).
Temuan multivariat dapatkan variasi makanan yang berpengaruh signifikan dengan kadar hemoglobin pada anak pra sekolah $(\rho=0,000)$. Pada penelitian menunjukkan nilai $r=0,0636$ yang berarti variasi makanan berhubungan kuat dengan kadar hemoglobin. Nilai koefisien determinan R2 $=0,405$ yang berarti variasi makanan berpengaruh $40,5 \%$ terhadap kadar hemoglobin pada anak pra sekolah.

Berbeda pada penelitian dari malkanthi yang menjelaskan faktor-faktor yang secara signifikan terkait dengan anemia dalam regresi logistik multivariat, hanya durasi ASI eksklusif, asupan zat besi, dan pendidikan ayah (Riskesdas, 2013).

Variasi makanan dianggap sebagai indikator kunci dalam menilai akses, pemanfaatan, dan kualitas diet individu. Bukti dari analisis data menunjukkan ada interaksi antara variasi diet dan kadar hemoglobin pada kelompok umur anak. Hasil penelitian menjelaskan rata-rata energi anak adalah 831,35 $\pm 243,1$ yang masih di bawah AKG anak 4-6 tahun yaitu 1600 kal. Kurangnya AKG ini menjadi penyebab utama variasi makanan kurang (Saaka M \& Galaa SZ, 2017).

Diet monoton dengan variasi rendah akan menyebabkan kekurangan mikronutrien lainnya, makanan seperti lemak dan protein yang kurang dapat menganggu penyerapan nutrisi apa yang telah dicerna, dan energi (Thompson B, 2008). Pengaruh variasi makanan terhadap anemia telah teruji. Makanan yang bervariasi diharapkan melindungi terhadap anemia, beberapa penelitian lain telah melaporkan kurangnya asosiasi antara keragaman diet dan anemia, terutama di lingkungan di mana banyak faktor lain selain paparan diet dapat meningkatkan risiko terkena anemia.

Keragaman diet pada tingkat 
individu adalah ukuran kualitas makanan. Artinya, semakin bervariasi makanan semakin melindungi dari anemia. Oleh sebab itu pentingnya edukasi tentang keanekaragaman pangan bagi orang tua. Anak-anak yang mengkonsumsi, rata-rata empat kelompok makanan yang berbeda dapat terlindungi dari anemia (Saaka M \& Galaa SZ, 2017).

Sayangnya, peneliti tidak mengumpulkan informasi sistematis tentang cara pengolahan makanan anak, kebiasaan cara mengkombinasikan makanan, faktor makanan lain yang dapat menghambat penyerapan besi dan kami tidak mengumpulkan informasi terkait kondisi infeksi pada anak yang mempengaruhi penyerapan besi. Keterbatasan lain dalam penelitian ini adalah, karena sistem food record yang dicatat orang tua sendiri, kemungkinan orang tua lupa mencatat makanan atau memahami porsi yang sebenarnya bagi anak sehingga rata-rata asupan energi kurang dari AKG. Disarankan pada penelitian selanjutnya untuk meneliti tentang pola pengolahan dan penyajian makanan yang terkait dengan bioavaibilitas besi.

Kajian meta-analisis tentang pengaruh intervensi diet pada anak-anak dengan anemia. Intervensi diet memiliki efek yang menguntungkan pada anak-anak dengan anemia, karena didukung oleh peningkatan efek yang signifikan intervensi diet (Sun J et al., 2018). intervensi yang diharapkan adalah peningkatan jumlah asupan makanan, meningkatkan makanan yang kaya mikronutrient, meningkatkan penyerapan makanan dan cara penyajian makanan yang benar (Thompson B, 2008).

Pemberian intervensi makanan sendiri tidak terlepas dari peran penting sosioekonomi dalam keluarga. Faktor demografi, sosioekonomi faktor, struktur keluarga, air/sanitasi, pertumbuhan, kesehatan ibu dan penyakit baru-baru ini secara signifikan terkait dengan adanya anemia anak (Moschovis PP, Hayden D, Wiens WO, Arlington L, \& Antsygina O, 2017; Novaes TG, Gomes AT, Silveira $\mathrm{KCd}$, \& etall, 2017).

\section{KESIMPULAN DAN SARAN}

Berdasarkan hasil temuan diatas dapat disimpulkan bahwa jumlah asupan harian, asupan besi dan vitamin $\mathrm{C}$ saja tidak berpengaruh terhadap hemoglobin, melainkan diperlukan peningkatan asupan protein, pengaturan frekuensi makan terutama variasi dalam menu makanan.

Disarankan tenaga kesehatan agar dapat memberikan pendidikan kesehatan tentang pola makan. Strategi pola makan yang harus disampaikan adalah penambahan asupan, pemilihan bahan makanan, pengolahan, penyajian pada anak agar penyerapan besi dan pengendalian anemia dapat tertangani. Penelitian lebih lanjut diperlukan utuk efektivitas intervensi anemia dipopulasi prasekolah.

Temuan ini memberikan saran kepada pengambil kebijakan agar intervensi anemia pada anak tidak hanya sekedar pemberian mikronutrient saya, tetapi juga intervensi pendidikan kesehatan tentang gizi anak kepada orang tua untuk mengkombinasikan makanan, terkait variasi, frekuensi, asupan protein yang penting bagi pembentukan hemoglobin dan cara pengolahan makanan agar besi yang masuk dapat diserap dengan baik.

\section{DAFTAR RUJUKAN}

Chandyo RK, Ulak M, Adhikari RK, Sommerfelt H, \& Strand TA. (2015). Prevalence of Iron 
Deficiency and Anemia among Young Children with Acute Diarrhea in Bhaktapur, Nepal Healthcare, 2015 (3), 14.

Desalegn A, Mossie A, \& Gedefaw L. (2014). Nutritional Iron Deficiency Anemia: Magnitude and Its Predictors among School Age Children, Southwest Ethiopia: A

Community Based Cross-Sectional Study. Plos One, 2014, 13.

Gondim SSR, Diniz ADS, Souto RAD, Bezerra RGDS, Albuquerque ECD, \& Paiva ADA. (2012). Magnitude, time trends and factors associate with anemia in children in the state of Paraíba, Brazil. Rev Saúde Pública.

Janus J, \& Moerschel SK. (2010). Evaluation of Anemia in Children. American Family Physician, 81(12), 10.

Legason IL, Atiku A, Ssenyonga R, Olupot PO, \& Barugahare JB. (2017). Prevalence of Anaemia and Associated Risk Factors among Children in North-western Uganda: A Cross Sectional Study. BMC Hematology, 17(10), 9.

Malkanthi R. L. D. K. , Silva K. D. R. R. , \& Mudalige UKJ. (2010). Risk Factors Associated With High Prevalence Of Anemia

Among children under 5 years of age in paddy-farming

Households in Sri Lanka. Food and Nutrition Bulletin, 31(4), 8.
Moschovis PP, Hayden D, Wiens WO, Arlington L, \& Antsygina $\mathrm{O}$. (2017). Individual, Maternal And Household Risk Factors For Anaemia Among Young

Children in sub-Saharan Africa: a crosssectional study. BMJ, 2018(8), 14.

Novaes TG, Gomes AT, Silveira KCd, \& etall. (2017). Prevalence And Factors Associated With Anemia In Children Enrolled In Daycare

Centers: A Hierarchical Analysis. Rev Paul Pediatr, 35(3), 8.

Riskesdas. (2013). Riset Kesehatan Dasar. Jakarta: Kementrian Kesehatan RI.

Saaka M, \& Galaa SZ. (2017). How Is Dietary Diversity Related To Haematological Status Of Preschool Children

In Ghana? Food \& Nutrition Research,, $61,12$.

Sachdev HPS, \& Gera T. (2013). Preventing childhood anemia in India: iron supplementation and beyond. European Journal of Clinical Nutrition, 67, 6.

Sun J, Zhang L, Cui J, Li S, \& Lu H. (2018). Effect of dietary intervention treatment on children with iron deficiency anemia in China: a meta-analysis. Lipids in Health and Disease, 17(108), 6. 
80 Jurnal Terpadu Ilmu Kesehatan, Volume 9, No 1, Mei 2020, hlm 1-116

Thompson B. (2008). Food-Based Approaches For Combating Iron Deficiency. Rome.

WHO. (2011). Hemoglobin Concentration for the Diagnosis Of Anemia and Assesment of Severity. In W. H. Organization (Ed.), (Vol. 11). Geneva: VMNIS. 